\title{
The Leading Mid-European Astronomer Marian Wolfgang Koller
}

\author{
Stanislav Južnič \\ Dunajska 83, \\ Ljubljana 1000, Slovenia \\ Email:juznic@hotmail.com
}

\begin{abstract}
Marian Wolfgang Koller used to be considered the very best astronomer from Carniola next to Augustin Hallerstein. Today, his work connected with the Dalton Minimum is again in limelight as the alternative explanation of global warming phenomena. Koller wrote precise notes of six semestrial courses of Josef Stefan to promote Stefan's talents. By using the international connection of his patron Koller, Stefan published at least twenty articles in the British Philosophical Magazine, some of them also in Paris and Geneva.
\end{abstract}

Keywords: Bohinj in Carniola, Dalton Minimum, history of observational astronomy, Josef Stefan, Kremsmüster, Marian Koller, sunspots

\section{Introduction}

Wolfgang Marian Koller was born on 31 October 1792 in Bohinjska Bistrica no. 87 in Carniola. (Book of Baptisms, p. 27). His father Andreas Koller was the general manager of the Baron Zois' ironworks there.

In 1810/1811, during the French occupation of Carniola, Koller studied general chemistry, natural history, and mathematics (with the grade "l'optime") at the Central School (École centrale) in Ljubljana. Koller's patron, Baron Zois, wanted to have the young man trained at the Mining Academy in Banská Štiavnica, but his plan thwarted due to the unfavorable time conditions. Koller attended the University of Vienna and there devoted himself to mathematical studies in $1811 / 1812$ under the famous astronomer Johan Tobias Bürg. 


\section{Professor and guardian of the physics cabinet in $1826-1839$}

Koller became a Benedictine at Kremsmünster Abbey with the monastic name Fr. Marianus. Following the death of P. Thaddäus Derfflinger (1748 - 18 April 1824), director of the observatory famous for his observations of sunspots, the leaders of philosophical studies and directors of the convict and observatory called Koller back to the Abbey to become a professor of natural history at the Philosophical Institute, which he started in the school year 1824/1825. At the beginning of November 1824, he provisionally took up that professorship. Additionally, he took over the professorship of physics after proper preparation in 1826. On 17 February 1827, he passed the strict exam for both subjects in one day at the k. k. Lyceum in Linz with excellent results, after which the court confirmed him as a full professor of both sciences.

For almost a decade and a half, Koller took care of the physics laboratory needed for lectures in the abbey (Fellöcker, 1864, pp. 258-261). Among other things, he purchased several devices related to vacuum techniques:

In 1833, Koller acquired the Windbox (Windbüchse 'air rifle', 'wind rifle') as an airgun designed by a clockmaker and ironmonger Bartolomeo Girardoni (Girandoni, 1729-1799) around 1779. From 1780, it was also used by the Habsburg army. The device was donated by Friedrich Häusler, a monastery economist. Also, Koller got a device proving Mariotte's law for compressed and diluted air (Fellöcker, 1864, p. 259).

Koller used Plateau's anorthoscope and, on 8 December 1835, he additionally received a similar stroboscope, designed by Koller's friend Simon Stampfer (Fellöcker, 1864, p. 260).

In 1827, Koller acquired an instrument for presentation of all important electromagnetic experiments of Oersted and Ampère, the so-called Ampère frame. It was designed according to Baumgartner's description, communicated in the first volume of Baumgartner's and Ettingshausen's Viennese Journal Zeitschrift für Physik und Mathematik in 1826. Koller bought it at a price of 200 fl (Fellöcker, 1864, p. 261). 


\section{Director of the observatory in 1830-1847: The beginnings}

After the unexpected death of astronomer P. Bonifacius Schwarzenbrunner (1790 - 29 April 1830), Koller took over the management of the observatory in Kremsmüster. Koller consequently gave up the professorship in natural history at the end of the school year in 1830. Koller retained the Chair of Physics until the end of the academic year of 1839 while he devoted his energy to the service of astronomy.

After the death of the director of the k. k. Observatory in Vienna, Joseph Johan Edler Littrow (1781 - 30 November 1840), Koller was recommended as his successor. After long negotiations, the request was "rejected," but already the proposal itself fully honored Koller's personal merits. In 1842, Littrow's son Karl Edler Littrow was elected. Of course, he gladly collaborated with Koller.

Koller's knowledge and achievements as a professor and astronomer, his experiences, and merits as head of a well-attended educational institution created a great impact on the broadest circles. Therefore, after the death of astronomer Cassian Hallaschka (Halaška, 1780 - 12 July 1847), Koller was chosen to fill his position as the member of the Government Commission for Higher Education heading all philosophical institutes, technical schools, naval schools, mining schools and forestry academies throughout the monarchy. The son of the former director of the Carniolan Idrija mine, Count Karl Borromäus Rudolf Inzaghi (1777-1856), visited Koller in Kremsmüster on 22 September 1847 (Fellöcker, 1864, p. 242). On 30 October 1847 , Koller was appointed to his new prestigious job as government councilor for the philosophical courses and technical studies under Count Karl Borromäus Rudolf Inzaghi and two other presidents of Study Court Commission, with Andrej Mešutar as Koller's colleague there. While residing in his abbey's Renaissance Benedictines' palace Kremsmünsterhof at Annagasse 1003 (now no. 4), south of Stephansdom in the Viennese Innere Stadt, Koller also became the president of the Philosophical Faculty of the University of Vienna (Hof- und Staats-Handbuch, 1848, pp. 228, 236, 284; 1853, pp. 72, 148, 180; 1866, pp. 48, 144, 151, 237).

Koller took up his new duties at the beginning of December and soon found his way in his new influential sphere.

To recognize and honor Koller's services to the sciences, the Imperial Academy of Sciences in Vienna chose him as their full member on January 26, 1848, which the emperor confirmed on February 1, 1848. 
When he left Kremsmünster, Koller had no idea how fateful the year 1848 would be for Europe, especially for Vienna; but in the midst of all the dangers and turmoil he persevered bravely in his place and in office, and only retired to the Melk Abbey for a few days at the end of October, from where he returned at the beginning of November.

When, in 1849, the k. k. Supreme Study Court Commission was dissolved and a Ministry of Worship and Education was provisionally established in its place, Koller became counsellor of the section responsible for secondary schools, polytechnic, nautical and astronomical institutes. Koller's fellow court counsellors were Andrej Mešutar and philosopher-Herbartianist school reformer Franz Serafin Exner (1802-1853), while Johan Kleeman was a section counselor. They worked under Exner's Prague University student, the minister, and founder of political Catholicism, Count Leopold Thun-Hohenstein (Leo, 1811-1888) until the downfall of Bach's absolutism in 1860. As the opportunist Kleeman then already quarreled with his former collaborator Janez Bleiveis, the leader of Old Slovenians, Kleeman might have had more troubles with Thun-Hohenstein's nationalist politics, as Thun-Hohenstein was a personal friend of the leader of the Federalist Old Czech Party Protestant historian František Palacký (17981876). They promoted Austroslavism which may also have been Koller's option (Hof- und Staats-Handbuch, 1853, pp. 72, 148, 180).

When Koller took over the management of the observatory in 1830, Joseph Johann Littrow and Simon Stampfer helped Koller's activation of the two feet wide circle of meridians. In July 1831, the regular observations started, which have been continued until now without interruption (Fellöcker, 1864, p. 244). He measured the position of the Moon, the stars in parallel with the Moon, the planets, and many fixed stars.

In 1831, Koller designed a rotunda with a stone pillar and a rotating dome on top of the observatory to accommodate a portable equatorial. Equatorial was a measuring instrument for the accurate determination of stars in the 19th century. It is an equatorially mounted, long-firing telescope with large, finely divided circles and reading microscopes. In contrast to the meridian circle, it also enables the measurements of declination differences outside the meridian. The lens of Koller's equatorial had an aperture of 28 lines, 9-inch hour circle, and the declination circle 12 inches in diameter. The hour circle, together with declination and distance from the planet's centre of mass, determines the location of any celestial object. It is the great circle through the object and the two celestial poles as a higher concept than the meridian defined in astronomy, 
which takes account of the terrain and depth to the centre of Earth at a ground observer's location.

\section{Director of the observatory in 1830-1847: The world opened wide in summer 1838}

In the spring of 1838, Professor Andreas von Ettingshausen invited Koller to travel through northern Germany and then significantly larger Denmark, London, and Paris. A desirable and highly attractive opportunity to expand the circle of his knowledge, and meet the scientists with whom he was already in the learned correspondence. Koller, unlike seasick Hallerstein or Josef Stefan, just loved to travel. Stefan, of course, grew up in a much humbler environment, where extensive travel was an unattainable luxury.

Baumgartner was initially preparing to join them, but in 1833 he fell ill with throat problems. He limited his Viennese lectures as his voice failed him, and finally canceled his participation in the trip (Folk \& Holovatch, 2020, p. 4). On 18 July 1838, Ettingshausen, Marian Koller, and August Kunzek von Lichton (1795-1865), professor of physics at the university in Lviv, left Vienna for Prague. There they visited Ferdinand Hessler (1803-1865), university professor of physics with applied mathematics, Karl Wersin (1803-1880), professor of mechanics and physics at the Polytechnic, and Christian Doppler, professor of mathematics at the Polytechnic. Of course, they avoided contact with the antimilitarist Bernard Bolzano, who returned to Prague only in 1832 . They then continued their journey to Berlin.

In Berlin, they stayed at the Hotel De Russie. On 22-23 July 1838, they enjoyed the company of a young Encke's Swiss student, Johann Rudolf Wolf (1816-1893), later a leading researcher of sunspots, and his Viennese friend, a lawyer-politician of the Frankfurt Parliament in 1848 Joseph Edler von Würth (1817-1855) (Wolf \& Larcher, 1993, p. 72).

Koller's first visit was to the Berlin Observatory but, unfortunately, he did not meet its famous director Johann Franc Encke. The Berlin astronomer Johann Gottfried Galle (1812-1910) was the friendly guide for Koller, his travel companions, Wolf and Würth through the rooms of the excellent observatory. Later in 1846, Galle was the first to purposely observe the planet Neptune, which Urbain Jean Joseph Le Verrier (Leverrier) predicted by calculation, to 
astonish all European astronomers. Koller's predecessor, the Benedictine Placidus Fixlmillner (1721-1791), among others, calculated the orbit of Uranus.

Koller and his fellow travelers used their days up to 25 July 1838 to visit mechanicians such as the former Alexander von Humboldt's optician August Daniel Oertling (1803-1866) with his apprentice half-brother, later London optician Ludwig August Friedrich Oertling (1818-1891), the microscope manufacturer Friedrich Wilhelm Schiek (1790-1870) and Wilhelm Hirschmann senior (1777-1847). They were also received by Encke's Berlin astronomer, famous for his maps of Mars and the Moon, Johann Heinrich von Mädler (17941874), the chemist-crystallographer Eilhard Mitscherlich (1794-1863) and the first Jewish member of the Berlin Academy, Peter Theophil Riess (Gottlieb, 1805-1883), who brought Ettingshausen's letter to Koller's Kremsmüster on 23 April 1834, although Riess and Ettingshausen advocated the opposite theory of electricity. At Magnus' richly equipped cabinet, Koller and his companions performed several experiments, such as on the compression of water and various gases. They examined the sound of the Syrene under water which Koller also demonstrated in his lectures at Kremsmünster.

They left Berlin on the night of 25 July 1838 and went to Hamburg, where they arrived on 27 July 1838. While walking through downtown Hamburg, those travellers noticed a building that they immediately recognized as an observatory - it was the observatory of the navigation school. Its board director, the former British astronomer Carl Ludwig Christian Rümker (1788-1862), welcomed the Habsburgian travelers in a very friendly manner and readily showed them how to set up their own observatory.

At 11 o'clock in the morning, they visited in Altona the conference counselor Heinrich Christian Schumacher, the famous editor of Astronomische Nachrichten. Schumacher told the travelers that he was expecting Sir John Herschel's visit the following day and invited them to postpone their departure to London for a few days.

In the meantime, Koller and his companions met the naval clockmaker Hendrik Johan Kessels (1781-1849) in then Danish Altona, while in Hamburg they visited the Repsold brothers Adolf (1806-1871) and Georg. They examined Schumacher's excellent collection of instruments, where Koller saw his first planimeter.

On 29 July, during a friendly dinner at Schumacher's headquarters, the travelers joined Sir John Herschel, Kessels, later Schumacher's replacement at Altona and 
as the editor of Astronomische Nachrichten Christian August Friedrich Peters (1806-1880), Rümker and the Repsold brothers.

The next day, Koller and his Habsburgian friends explored the workshop of the Repsold brothers. There, the Repsolds manufactured the large meridian circle for the observatory at Pulkovo of Friedrich Georg Wilhelm von Struve (1793-1864) and Peters, who joined the staff of Pulkovo in 1839. Sir John Herschel in detail inspected its lens unit made at the famous Fraunhofer Institute in Munich. Koller soon ordered many devices from the masters he met on those journeys. Fraunhofer died a dozen years earlier, but his optical instruments were still famous.

Herschel travelled to Göttingen to meet Gauss and certainly also went to the neighboring Hanover to see his famous Jewish aunt, astronomer Caroline Lucretia Herschel of a small stature and a big heart.

On 1 August, after a pleasant farewell to friends in Altona and Hamburg, the travelers boarded a steamer for London in the company of Sir John Herschel (Fellöcker, 1864, p. 269). The ship had to face headwinds, so the travelers did not arrive in London until 6 p.m. two days later.

On 4 August 1838, they visited the Adelaide Gallery, an institute of practical sciences for the exhibition of objects with many amusements that has existed since 1834. It offered numerous objects, paintings and drawings from the fields of physics, natural history, chemistry, and technical sciences. The inventor, Edward Marmaduke Clarke (1805/1806-1859) was their friendly guide through the gallery.

On August 6, Koller and his accompanying gentlemen visited John Herschel's home for breakfast. President of the Royal Astronomical Society Francis Baily (1774-1844), Wheatstone and Babbage joined them. Afterwards, Babbage led the guests into his house and explained them their projected computing machine a decade after Babbage had visited the Carniolan Postojna cave to get his samples of Proteus. On 17 July 1828, he signed himself at the book of Postojna guests on his way from Florence to Vienna and Berlin. From August 30 until October 6, 1828, Humphry Davy and the physician John J. Tobin were in Ljubljana and afterwards crossed the Postojna area on their way to Trieste and on their way back they stayed in Postojna again until October 13, 1828 (Južnič, 2005, pp. 215-216). Babbage or Zois' friend Davy, or both, might have met Koller on that occasion as Koller also loved to visit his native areas. On October 22, 1825, Koller also acquired a 
Proteus during his trip to Venice and donated it to the collection of his domestic Kremsmünster monastery; he had it captured in Magdalena Cave near Postojna in Carniola and preserved it until August 1828. In October 1828, he brought another Proteus to the monastery, who lived until July 1829 (Fellöcker, 1864, p. 145). Koller somehow inherited the habit of observation of Proteus from his patron Zois, who used to acquire his "human fish" from his estate near Stična in Lower Carniola. In addition to many other associations, Koller as a devoted Bohinj native became a member of the agricultural societies of Austria, Lower Austria, and Carniola, as well as a member of the Museums societies of Upper Austria and Carniola (Fellöcker, 1864, p. 253).

The following day, the Habsburgian guests visited Wheatstone's cabinet at Somerset House, where the small shy genius Wheatstone presented his electromagnetic telegraph, his speech machine, the tool to determine the speed of light, a device for interference of sound, etc. Then they paid a visit to the meteorologist John David Roberton (1800-1843), the assistant secretary of the Royal Society. Koller gave him the meteorological observations made for Herschel in Kremsmünster. The guests visited the Society's library, where Newton's manuscripts and his first telescope are kept. Later they visited Baily, to whom Koller handed over the data about 208 fixed stars newly observed at the meridian circle of Kremsmünster.

This was followed by Koller's visits to Babbage and John's grandson George Dollond (1774-1852), where they saw many beautiful optical and other physical instruments, especially a new polarizing instrument designed by George Biddell Airy.

On 9 August 1838, they visited Slough, Windsor, and Eton. In Herschel's garden at Slough, the travelers looked at the famous giant telescope of the late Sir William Herschel. On 10 August, in Faraday's headquarters they admired the large battery of Humphry Davy, a great fan of Slovenian Alpine tours. On August 11, Koller visited the Greenwich Observatory.

Over the following days, the travelers toured the curiosities of London and visited the Adelaide Gallery again, where they were experimenting with the microscope filled by hydro-oxygen gas.

On 15 August 1838, Koller visited the First Lieutenant William Samuel Stratford (1791-1853), the Superintendent of the Nautical Almanac, who published in his volumes all the works of Koller up to date as notes from Koller's yearbooks of the observatory in Kremsmünster. Certainly, Koller also promised to send his new observations which were indeed published in London in the following years. 
On 17 August 1838, Koller went to Greenwich again to visit the famous Director Airy, who warmly received him.

After visiting London's most remarkable places of interest, the scientific institutes and museums and befriending the scientist, the travelers left the metropolis of England extremely satisfied with their sixteen-day stay. On 19 August, they sailed to Antwerp, and continued their journey to Brussels.

On 21 August 1838, in Brussels, they visited Adolphe Quetelet's observatory and the museum; the next day, they carried out experiments on radiation and with the anorthoscope of Quetelet's doctoral student Joseph Plateau. Wolf tried to find Quetelet several weeks later, on 14 and 16 September 1838, but to no avail (Wolf \& Larcher, 1993, p. 80; Lutstorf, 1893, pp. 10, 12, 16, 22-24).

On the evening of 22 August, Keller and his companions left for Paris, where they arrived at 8 a.m. on 24 August 1838 .

On 27 August, after a visit to the clockmakers Henri-Prudence Gambey (17871847) and Louis François Clément Breguet (1804-1883), Koller went to the meeting of the Parisian Académie des sciences, where he met Arago, Bouvard, Savary, D. Poisson, the mathematician Leonhard Christoph Sturm (1669-1719), the chemist Michel Eugène Chevreul (1786-1889), the zoologist André Marie Constant Dumeril (Duméril, 1774-1860), the geologist Alexandre Brongniart (1770-1847), the volcanologist-botanist Jean-Baptiste Geneviève Marcellin Bory de Saint-Vincent (1778-1846), Babinet, the researcher of phase transitions Cagniard de la Tour (1777-1859), and Alexander von Humboldt.

On 28 August, they visited the Parisian observatory, where the director Alexis Bouvard (1767-1843) kindly presented his instruments.

On 3 September 1838, Koller spent his evening at the headquarters of Jacques Babinet (1794-1872), where they carried out various interesting optical experiments focused on crystallography, rainbow and masses of planets.

On September 4, Félix Savart (1791-1841) showed the travelers his labs at the Museum du College de France, where Jean Claude Eugène Péclet (1793-1857) was also present. Later Koller visited Claude Servais Mathias Pouillet (17901868 ) in the Conservatoire des arts et manufactures. Later in 1879, Koller's protégé Josef Stefan in his famous paper determined the temperature of the Sun by using the measurements of Pouillet and the experiments of Genevan Professor Charles Soret to calculate the first meaningful value of the solar temperature estimated as $5580^{\circ} \mathrm{C}$. 
Over the following days, the travelers met Arago, Cauchy, Charles Chevalier (1804-1859), and others. Cauchy had just returned from Gorizia, and Ettingshausen had already consulted him about optics earlier in Prague in September 1834. Then Koller and his friends made excursions around Paris.

On 12 September, they began their return trip via Freiburg im Breisgau, where they joined the meeting of German natural scientists and doctors. Koller and his fellows attended some meetings and he befriended the Berlin geologist Leopold von Buch, Oxford geologist William Buckland (1784-1856), the Munich botanist Karl Friedrich Philipp von Martius (1794-1868), the Basel researcher of electrical polarization Christian Friedrich Schönbein (1799-1868), the Heidelberg physicist and president of the Physics-Astronomy-Physical Geography Section of that meeting Georg Wilhelm Muncke (1772-1847), the Würzburg chemist as a secretary of the Physics-Astronomy-Physical Geography Section of that meeting Gottfried Wilhelm Osann (1796-1866), the optician Wilhelm Eisenlohr (1799-1872) from the Karlsruhe Polytechnic, and others.

On 20 September, Koller and his friends traveled to Augsburg, where they visited the famous Augustinian astronomer and meteorologist Augustin Stark (17711839), and then went to Munich.

In Munich, they visited Carl August von Steinheil (1801-1870), who presented them the telegraph he had constructed, a centrifugal machine, the heliotrope, a magnetometer, and the idea of a new heliostat. Their rest of the day was devoted to some of Munich's sights. On September 24, Ettingshausen and Koller debated about the lightning rod at the Freiburg meeting (Leuckart, 1840, p. 63).

On the morning of 27 September, their host was Johann Lamont (1805-1879). Lamont had excelled as an early observer of Neptune seven years later. In addition to the beautiful optical instruments from Fraunhofer's famous workshop, Lamont presented to Koller and companions his instruments for determining the hourly averages of the pressure of air and its temperature, a machine for calculating refraction, and another tool for reducing the mean locations of the stars to apparent ones. Lamont's new micrometer on the large refractor attracted special attention as Koller needed those aids for his own research.

On the evening of that same day, the travelers left Munich. Koller returned from Linz to Kremsmünster. 


\section{Director of the observatory in 1830-1847: Back home with great knowledge}

Koller's journey bore fruit in the most gratifying way. Until then, Koller was a famous natural scientist only in the Habsburg monarchy as almost an autodidact in theory and practice. During his European tour, Koller learned a lot of novelties. As far as the funds were available, instruments were immediately bought, and others ordered. Koller's observatory's workshop and the physics cabinet soon received equipment that matched the progress made in the natural sciences worldwide.

His personal acquaintance with the most excellent professional authorities was followed by lively correspondence. Koller returned home rich in gifts of books, and the prospect of sending further series of his observations was promised.

The Danish conference councilor Heinrich Christian Schumacher travelled to Vienna to observe the total solar eclipse on 8 July 1842 . He then visited Koller in Kremsmünster and stayed at the monastery for several days. Their collaboration became particularly important for Koller's observatory because Schumacher carried eight chronometers with him to determine the difference of the geographic longitudes between Vienna (today's value: $16.3062=16^{\circ} 10^{\prime} 58^{\prime \prime}$ to $\left.16^{\circ} 34^{\prime} 43^{\prime \prime} \mathrm{E}\right)$ and Kremsmünster west of Vienna (14.1315 = $\left.14^{\circ} 7^{\prime} 53^{\prime \prime} \mathrm{E}\right)$. Because of the Earth's rotation, there is a close connection between longitude and chronometric time. For the difference of geographic latitudes between Vienna $\left(48^{\circ} 12^{\prime} 30^{\prime \prime} \mathrm{N}=48.1441 \mathrm{~N}\right)$ and Kremsmünster west of Vienna ( $48^{\circ} 3^{\prime} 13^{\prime \prime}$ $\mathrm{N}=48.0537 \mathrm{~N}$ ) they measured $8^{\prime} 59^{\prime \prime}$, while today's value is somewhat higher. That result with the other previous determinations harmonized down to the small error of $0.05 \mathrm{~s}$.

Schumacher also carried a normal barometer, which was exactly balanced to that of the Paris Observatory. A multiple comparison with Koller's main barometer showed the needed correction of +0.432 Paris lines (ligne equals $2.2558 \mathrm{~mm}$ ), which has been applied to all observations since then. The previous observations were also improved.

When Koller took over the management of the observatory, he paid particular attention to meteorological observations. For this purpose, new instruments were purchased, corrected according to the best methods, and the apparatuses which had been previously used were compared with the new ones to enable the 
improvement of older observations; the number of daily records was increased and the system of observations expanded. After 1831, air pressure, temperature, vapor pressure, humidity of the air, types of clouds, velocity of clouds, density of clouds, wind direction and strength, type and amount of precipitation, notes of special phenomena and a brief characteristics of the everyday weather were included.

Such material was not left unused: the daily, monthly, and annual averages of all observation data were calculated and compiled and published in an overview table at the end of each year.

From 1836 onwards, Koller's observatory also took part in meteorological observations, which were carried out in 1840 on John Herschel's suggestion during the times of equinoxes and solstices.

In 1840 and 1841, Koller did a very meritorious job by determining the hourly heat flow for Kremsmünster from the rich material of temperature observations from 1820 to 1839 according to Bessel's method for calculating periodic natural phenomena. He published it in 1841 in the annual report of the Francisco Carolinum museum in Linz; in an appendix to his article, he added a report 'On the temperature of spring water in Kremsmünster'.

A similar work was completed by Koller in 1843 under the title 'On the hourly changes in vapor pressure and humidity in the air' based on ten years of psychrometric observations (1833-1842) in Kremsmünster. It was published in the annual report of the Francisco Carolinum museum in Linz for the year 1843. That work was very deserving, since at that time only a few labs continued such prolonged uninterrupted series of observations of haze, pressure and relative humidity.

In the 1840s, at the suggestion of great scholars including Alexander von Humboldt and Carl Friedrich Gauss, the Earth's magnetism attracted the general attention of natural scientists. Within a few years, this branch of natural research was developed into an independent science. Certainly, Koller did not want to stay behind. For more than a century, the Kremsmünster's scientific studies were operated with preference, in tune with the worldwide contributions to the research of the Earth's mysterious magnetic force. Koller founded his magnetic observatory in August 1839. At the time of its creation, it was the second in the Habsburg Empire after Kreil's in Milan. Koller set up a Gaussian magnetometer in the large, beautiful observation room of the observatory, with a 4-pound 
rod needed to observe the variations in magnetic declination. Soon, in 1840, a bifilar apparatus with a 25 -pound rod was used to observe the variations of the horizontal intensity.

Since 1815, determinations of magnetic declination with a declinatorium of Georg Friedrich Brander (1713-1783) have been made in Kremsmünster from time to time. Since 1832, Koller regularly performed them at the beginning or end of each month in the morning and afternoon, but that work did not provide the desired reliability due to the imperfect setup of the instrument. Koller accomplished his first observations with the variations declinatorium in August 1839 and published his findings in 'Gauss' and Weber's results of the magnetic association' from the year 1839. That journal, Resultate aus den Beobachtungen des Magnetischen Vereins, was edited by Carl Friedrich Gauss and Wilhelm Weber in 1836-1841. Starting from October of 1840, none of the data needed for the Göttingen collections and the one collected by the Royal Society in London has been neglected, unless there have been great obstacles.

Koller enjoyed the strongest support in this arduous work by the observatory staff, many professors, and younger members of the monastery. His results were published in Gauss' and Weber's Results of the Magnetic Association and in Lamont's Annals for Meteorology and Earth Magnetism.

In 1854, a complete compilation of all magnetic observations and determinations made from 1839 to 1850 (inclusive) appeared in Kremsmünster under the title 'About the magnetic observatory in Kremsmünster and the results derived from the observations from 1839 to 1850 by P. Augustin Reslhuber, director of the observatory'. The item was printed in Vienna by the imperial court and state printing house.

In June 1841, Koller built an iron-free station made of wood in the large abbey garden, far from all buildings, in which a Gaussian unifilar (single-file) magnetometer with a 4-pound rod was permanently installed to determine the absolute declination and horizontal intensity. From time to time, absolute determinations of the magnetic quantities and comparisons of the data of this apparatus with the variation apparatuses located in the observatory were carried out.

At the beginning of 1841, Koller recorded the state of the variation instruments three times a day at 8:00 a.m., 2:00 a.m. and 8:00 p.m., according to the local time of Göttingen. Those measurements are resumed to this day, so that Kremsmünster observatory has the longest continuous series of daily magnetic observations in the areas of former Habsburg empire. 
Before his appointment to Vienna, Koller also initiated the acquisition of a Repsold inclinatorium, which was only completed in 1848, after Koller's departure. With these instruments, Koller made multiple determinations of inclination in Vienna in 1848 and 1849 and sent them to the Kremsmünster observatory in June 1850. Koller acquired a portable passage instrument with 19' 5" lines of lens' aperture and a focal length of 21 inches for his iron-free magnetic observatory, including a golden pocket chronometer from H. Kessels' manufacture catalogued as No. 1304 at the Kremsmünster observatory.

Koller's contributions immensely enriched the Kremsmünster observatory, and all the scientific collections connected to it, including the natural history collections, the physics cabinet, and the natural science library. Some branches he completely redesigned, and the magnetic observatory owes its new foundation to Koller, so that Koller's era will always remain as one of the most brilliant ones in the annals of the college and the observatory.

With his departure to Vienna, Koller did not terminate the association with Kremsmünster and the observatory that had become so dear to him, but remained from then on the observatory's most devoted benefactor. Every year, professional business and health allowing, he visited his dear observatory, always accompanied by his loyal friend Simon Stampfer, and empowered a valuable circle of scientists at Kremsmünster whenever he visited the monastery.

In 1857 , Koller contributed a significant sum to the acquisition of a new refractor with 68 Parisian lines of lens opening, and the observatory's dialytic telescope, a type of achromatic telescope with a second correcting lens, from the Viennese workshop of Simon Plößl (1794-1868). It had 37 lines of lens opening and 40 inches focal length. In 1861, they followed the latest principles worked out by the head of the astronomical-mechanical workshop of the polytechnic institute in Vienna, Gustav Starke (1832-1917), the son of Georg Christoph Starke (17941865). He made for Kremsmünster a passage instrument with a telescope. It had 24 lines of lens aperture and 24 inches of focal length. It had vertical circles with a diameter of 10 inches and horizontal circles with a diameter of 8 inches. With his gifts, Koller also enriched the library with numerous valuable works of scientific content.

Koller did not renounce science after his appointment to the civil service. Rather, through long-term care, this had become a necessity for him, in his hours of rest, as relaxation. He published several treatises during this time and left many manuscripts. In 1849 , with his newly acquired $\mathrm{PhD}$ in philosophy, 
Koller even appeared as a docent at the University of Vienna and read his lectures "on spherical astronomy", which were characterized by precision, clarity and beautiful language and were frequently visited. Koller also liked to attend the lectures of younger professors, partly for his own instructions, partly to honor them. So, Koller attended the lectures by professors Dr. Josef Petzval, Dr. Fr. Moth, Dr. Carl Hornstein, Dr. Josef Stefan and, in Koller's last summer semester, that of Dr. Theodor Oppolzer, which he did not merely sketch out in the lecture rooms, but fully worked out at home and wrote down. In addition, he set up a small observatory for astronomy and meteorology in his apartment, insofar as space allowed, and provided himself with instruments from the best masters.

Ernst Wilhelm Ritter von Brücke (1819-1892) recommended Josef Stefan to the counsellor of the Ministry for Education and Religion, the Benedictine Marian Koller. Koller personally attended six of Stefan's semestrial courses in 18621864, the last one also in the company of young Ludwig Boltzmann. Koller filled hefty booklets with notes about Stefan's lectures to promote Stefan's talents (Koller, 1861-1864, see Fig. 1). As a native Carniolan, Koller had a special sympathy for Stefan's Slovenian origin. In Klagenfurt, Stefan had graduated from the Benedictine grammar school when Marian Koller's younger brother Andrej was a mayor there from 10 November 1850 to 13 April 1852. Stefan was a Klagenfurt student of Andrej's brother-in-law, the Slavicist Anton Janežič at the Benedictine headmaster Karl Robida's class, which especially pleased Koller. Upon Koller's recommendation, Stefan became the youngest professor of physics and mathematics at the University of Vienna and the co-director of the Physics Institute on 9 March 1863, full member of the Academy of Sciences in Vienna as the first recipient of Ignaz Lieben Prize on 27 April 1865, and the director of the Institute of Physics in Vienna after Ettingshausen's retirement by imperial order on 1 October 1866, a dozen days after Koller's death (Stefan Archive, Wien 106.I.3988; Höflechner, 1994, p. 15). By using the international contact with his patron Koller, Stefan published at least twenty articles in the British Philosophical Magazine, some of them also in Paris and Geneva. Those also included the early formulations of the now famous Stefan problem of the boundary between solid polar ice and liquid that moves freely over time, which is often used in modern multiphase systems research. Therefore, Stefan used the mathematical physics of French experts of Joseph Fourier's school whom Koller befriended during his stay in Paris. Stefan might have been Koller's greatest discovery, just like Faraday was Humphry Davy's greatest discovery. 
Koller rarely missed sessions of the Imperial Academy of Sciences, except during his last two years when he was overburdened by other duties. Therefore, many members of the academy who were close to him mourned his death, including the mineralogist Franz Xaver Maximilian Zippe (1791-1863), Kreil, president of the academy Baron Baumgartner, and especially Koller's friend Stampfer.

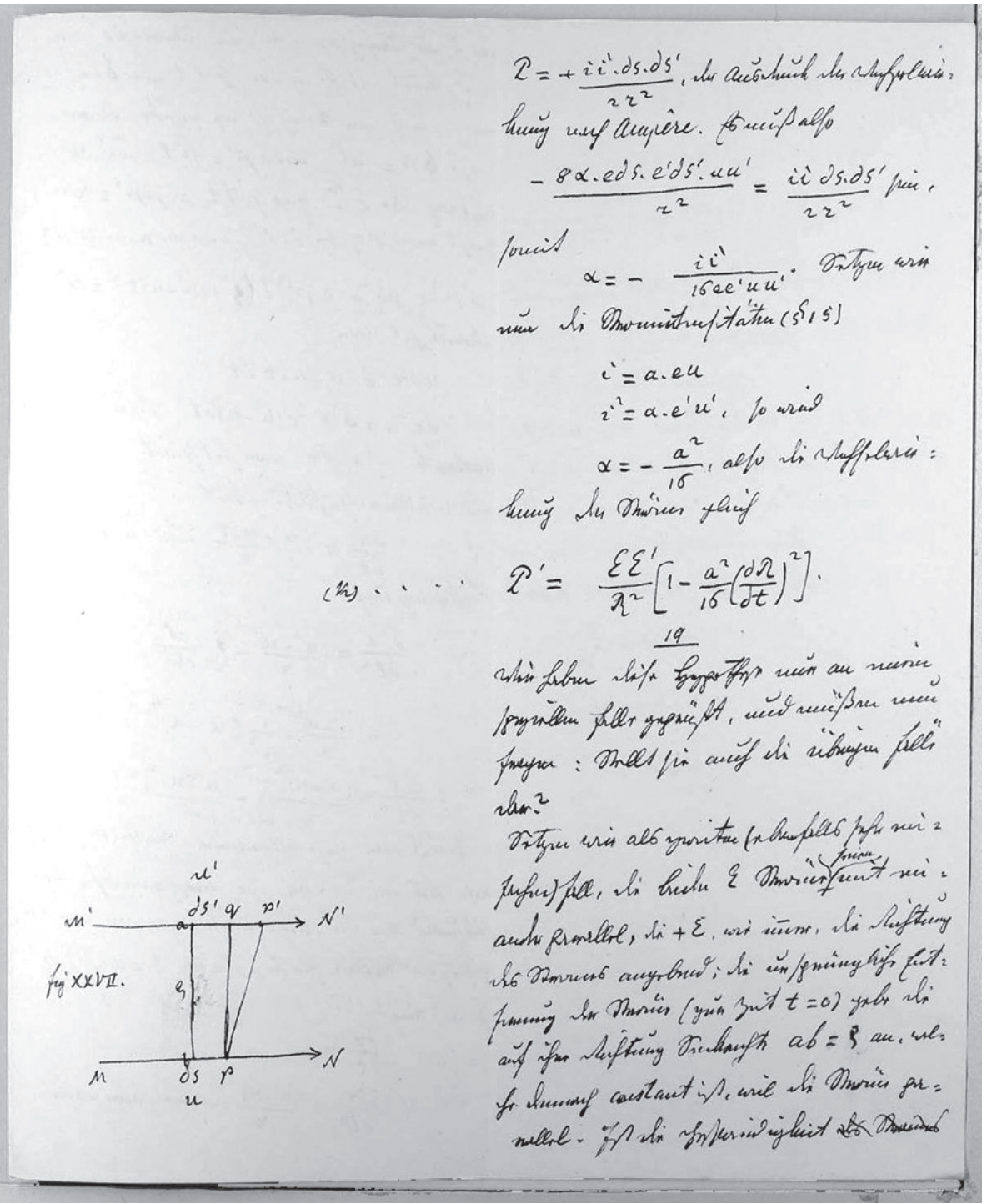

Figure 1. Koller's note of Stefan's eighth lecture on Ampère's electrodynamic on 23 June 1863 (Koller, 1863, p. 68). Photo by P. Amand Kraml, Sternwarte Kremsmünster. 


\section{Koller for Habsburgian African missions}

Koller supported Ignatius Knoblehar (Knoblecher, Abuna Soliman, 1819-1858), the pioneer of the missions in Sudan, the explorer of the White Nile, and his predominantly Slovene and Tyrolean colleagues. Koller joined the fraternity Mary's Society for the Promotion of Catholic Missions in Central Africa (MarienVerein zur Beföderung der katholischen Mission in Central-Afrika, MarienvereinsComité), founded in Vienna in 1850 and promoted by all Habsburgian bishops for fundraising. In the annual reports of that society, Jahresberichte des Marienvereins zur Beförderung der katholischen Mission in Central-Afrika, Knoblehar's reports about his sailing on the ship Stella Matutina ('Morning Star') were printed. The first seven volumes (1852-1858) of those reports were concluded by Fries' reports on the collection of contributions with the emperor himself among the donators. Along with Koller, a member of the fraternity was Andreas Meschutar (Mešutar, 1791-1865) as a nominal bishop in Serdica since 1853, court counsellor, member of the Carniolan agricultural society, honorary member of Academy of Sciences in Vienna, section head of the Ministry of Culture and leader of the MarienVerein zur Beförderung der katholische Mission in Central-Afrika. Among the members were also the son of Koller's former employer Moritz II Count Fries von Friesenberg (1804-1887) as treasurer of the fraternity, the Viennese parliament deputy for Styrian areas, west of Graz, including Hartberg, Feldbach, Weiz and Fürstenfeld, in the 1870s on centralist liberal side, Karl von Hammer-Purgstall (1817-1879), the son of the first president of the Academy of Sciences in Vienna, the orientalist Baron Joseph von Hammer-Purgstall (1774-1856) of Carniolan origin, doctor of jurisprudence, ministerial counsellor of the Ministry of Trade, a Catholic of Jewish origin Carl Ferdinand Knight Hock (1808-1869), the priest of St. Peter's Church in Vienna and the consistorial counsellor Jesuit Maximilian Leopold Horny (Horni, 1787-1857), Joseph Hammer-Purgstall's collaborator at the Ministry for Foreign Affairs, court counsellor and former Swiss Protestant Friedrich Emanuel von Hurter-Amman (1787-1865). Among other members of the fraternity were the chamberlain of Central-Severinus Verein Count Heinrich O'Donnell and also Hurter-Amman Emanuel as a member of Central-Severinus Verein. Count O'Donnell was a relative of the Irish officer in the Habsburgian army Count Maximilian Karl Lamoral O'Donnell von Tyrconnell (Donel, 1812-1895) who saved the emperor's life in 1853 (Mešutar, 1851, p. 8; Kaiserseder, 2013, p. 66; Hof- und Staats-Handbuch, 1853, pp. 40, 52, 123, 152, 179, 345, 347). That international combination of former Jews, former Protestants, Irishmen, freemasons, German nationalists and a trade expert made the support for the 
Habsburgs' African imperialism extremely effective, except for the lack of quinine. One of the supporters of the Habsburgian African imperialism was the deputy president of the Viennese Geographical Society, statistician and freemason Baron Friedrich Wilhelm Otto Ludwig Reden (pseudonym Friedrich Wiemund, 18041857), former liberal leftist nationalist deputy of the Frankfurt Parliament, who had been forced to leave Hanover for Vienna in 1854 where he helped to organize the Statistical Congress in Vienna shortly before his death in 1857.

The Habsburgian efforts in Sudan benefited from the missionaries' activities. The Habsburgian ambitions were restricted to the development of regions of intensive trade controlled by the Habsburgians. The missionaries explored the unknown terrain, gathered resources, initiated barter trade with the natives along the banks of the White Nile and established the initial colonial education. Thus, they completed the first stages of colonization and so they are considered as a precursor of Habsburgian colonialism in Sudan (Kaiserseder, 2013, p. 145). Consequently, the former Habsburgians of Venetia and Lombardy colonized Sudan's neighbour Ethiopia under the Italian flag in 1936-1941.

Mešutar, Koller, Knoblehar, Dovjak and many others from Carniola made the Habsburg Sudanese missions partially Slovene (and Tyrolean), although the somewhat elitist Knoblehar preferred to see Tyrolean missionaries in his camp.

Knoblehar sent to Koller his scientific observations. He measured pressure with Heinrich Kappeller's barometer, determined temperature, wind direction, cloudiness, and the Blue Nile's water level at its junction with the White Nile near Khartoum. Those levels were in fact measured by Martin Dovjak (Dovyak, 1821-1854) in Khartoum on the banks of the Nile from 14 June 1852 to 14 November 1852, just before the poor guy died there on the spot. The measurements were then edited by Koller for publication in the bulletin of the Viennese Central Station for Meteorology and Earth magnetism, established on Koller's initiative and in the Viennese academic gazettes (Kreil, 1858, pp. 37-68; 1857, pp. 476-488; Reden, 1857, pp. 150-160; Lukas, 1859, pp. 499-527, 534-536; Knoblehar \& Koller, 1859a; 1859b, pp. 528, 529-533; Klun, 1851).

Kreil wrote on page 37 in 1859: "I owe your data to Minister Councilor Koller, sent to him by Pro-vicar Knoblehar". On page 66, he also summarized Knoblehar's notes on earthquakes. Later in 1865, Theodor Kotschy (Koczy, 1813-1866) wrote about Koblehar's plants stored in the herbariums of the Imperial Palace of Vienna after Kotschy's own travels along the Nile. 
Despite the idealized image of the Sudanese or the Mexican imperialist interventions of the Habsburgs a couple of years later (1864-1869), criticism also resonated, as it was in many ways an expensive adventuristic attempt. Despite being known in Peru since ancient times, in Europe the large-scale use of quinine against malaria started around 1850, too late for Knoblehar whose efforts collapsed with his death. Without the quinine most of Central and North Europeans could not withstand equatorial malaria. Therefore, Knoblehar's impossible attempts promoted the backhand colonialism of the dying Habsburgian empire. Without its traditional Turkish enemies onboard, the Habsburgians were desperately trying to hide their domestic national problems and ethnic conflicts.

Among the skeptics joining Knoblehar's missions was the Ljubljana gunsmithmaster Jakob Šašel (Schaschel, 1832-1902) who worked in Karlovac after his disappointed return from Sudanese Africa in 1857. Nikola Tesla knew him very well and in Karlovac Tesla frequently met his son, the writer and priest Jakob Šašel (1862-1911).

\section{Conclusions}

Koller's astronomy exceeded its historical values. His predecessor in Kremsmünster observed the John Dalton Minimum during the period of low number of sunspots in times of the reduced solar activity from about 1790 to 1830, corresponding to the period of solar cycles 4(6) to 7 (Hayakawa et al., 2020). Koller took over managing the observatory in 1830, but of course he had been involved in measurements for a decade and a half before, and later edited the notes of his predecessors. Like the earlier Maunder Minimum and the assumed even earlier Spörer Minimum, the Dalton Minimum coincided with a period of lowered Earth's globally averaged surface temperatures, reduced by about $1^{\circ} \mathrm{C}$ in the then German-speaking countries. Probably the parallel rise of volcanism is largely responsible for that cooling trend, as our ancestors survived the year 1816 without summer mainly caused by the explosion of Mount Tambora in Indonesia the previous year as one of the two largest eruptions in the last two millennia. Those increased volcanic eruptions were probably triggered by a simultaneous decrease in the solar incident energy levels.

Koller was certainly still interested in sunspots after he left Kremsmünster for Vienna. On 18 July 1850, on four pages he revalued and commented on 
Böhm's paper offered to the Academy of Sciences on 17 January 1850 and revised in Innsbruck on 2 February 1850. Josef Georg Böhm (1807-1868) was a professor of mathematics at the University of Innsbruck and replaced Kreil at Prague Observatory after that same publication in 1852. Böhm proposed for academic publishing his observations of sunspots for the determination of the solar rotation. Next, after Koller's evaluation in the same volume, his acquaintance Doppler defended the priority of his discovery of law now named after Doppler. After Koller's positive evaluation, Böhm's analysis of observations completed in 1832-1836 was published in Denkschriften of the Academy of Sciences in Vienna, followed by Bohm's other longer observations of sunspots in the years 1833, 1834, 1835 and 1836. Böhm observed sunspots as the assistant of Littrow from 2 May 1833 until 26 July 1836 in frequent collaborations with Koller's observatory nearby. Therefore, Böhm observed after the Dalton Minimum which lasted from 1790 to 1830 . Böhm noticed 88 sunspots in 149 observations. He edited them using analytical geometry and the Gauss' method of least squares. He used a cartography of the sunspots provided by the Jesuit Galileo's enemy Scheiner, Cassini and Philippe de La Hire's (1640-1718) early works, up to Lalande and the director of Paris Observatory Jean Baptiste Joseph Knight Delambre (1749-1822) (Koller, 1850, pp. 151, 152). Koller was still unaware of now the earliest known planned sunspot observation from 364 BC in the comments to the Chinese star catalogue compiled by Gan De (Lord Gan, Gan Gong, 甘德, born in the State of Qi, 4th century BC). Böhm concluded that the sunspots are equally frequent on both solar hemispheres. According to Böhm, the sunspots are infrequent around the solar equator and at solar latitudes above 35 degrees where they appear only rarely, while they occur most frequently in the intermediate zone (Koller, 1850, p. 153). The seventh solar cycle, at the beginning of Böhm observations, lasted for 10.5 years, beginning in May 1823 and ending in November 1833 (thus overlapping the Dalton Minimum). The eighth solar cycle lasted for 9.7 years, beginning in November 1833 and ending in July 1843, with its beginnings covering the majority of Böhm's observations. In fact, early in the approximately 11-year long solar cycles discovered by Samuel Heinrich Schwabe (1789-1875) in 1843 and promoted by Wolf, sunspots appear in the higher solar latitudes and then move towards the equator as the cycle approaches the maximum, following Spörer's law. Böhm did not notice that but tried to find the average latitudes, which does not make much sense according to the ideas which soon prevailed in his time. A decade after Koller's comments, Spörer's law predicted the variation of sunspot latitudes during a solar cycle. It was discovered by the English amateur astronomer Richard Christopher Carrington (1826-1875) around the year 1861. Carrington's work 
was refined by the German astronomer of Encke's Berlin Observatory Gustav Spörer (1822-1895). Both were just unknown teenagers during Koller's visits in their areas in 1838. Koller and Böhm provided no formal references except for Böhm's introductory notes on an earlier Littrow's paper and Böhm avoided any formalities thanks to Koller for his positive evaluation of Böhm's paper which we could expect today.

\section{References}

Böhm, J. G. (1852), 'Beobachtungen von Sonnenflecken und Bestimmung der Rotations-Elemente der Sonne; Beobachtungen von Sonnenflecken in den Jahren 1833, 1834, 1835 und 1836 (Beobachtungsort: Die k.k. Universitäts- Sternwarte in Wien), Denkschriften der kais. Akademie der Wissenschaften. Mathem. Naturw. Kl., Bd. 3/2, pp. 39-42.

Book... (1792), Book of Baptisms at Bohinjska Bistrica parish, no. 1, Archiepiscopal Archives, Ljubljana.

Fellöcker, S. (1864), Geschichte der Sternwarte der Benediktiner-Abtei Kremsmünster, Part I, Linz: J. Feichtinger's Erben.

Folk, R. \& Holovatch, Y. (2020), 'Crossing borders in the 19th century and nowtwo examples of weaving a scientific network,' Condensed Matter Physics (Ukraine), vol. 23, no. 2, art. 23001, pp. 1-15. http://doi.org/10.5488/CMP.23.23001

Hayakawa, H.; Besser, B. P.; Iju. T.; Arlt, R.; Uneme, S.; Imada, S.; Bourdin, P.-A. \& Kraml, A. (2020), 'Thaddäus Derfflinger's sunspot observations during 1802-1824: A primary reference to understand the Dalton Minimum,' The Astrophysical Journal, vol. 890, no. 2, pp. 1-10. https://doi.org/10.3847/1538-4357/ab65c9

Hof- und Staats-Handbuch (1844-1868), Hof-und Staats-Handbuch des Kaiserthumes Österreich, Vienna: Hof- und Staatsdruckerei.

Höflechner, W. (1994), Ludwig Boltzmann, Leben und Briefe, Graz: Akademisch Druck und Verlagsanstalt.

Južnič, S. (2005), 'Babbage’s calculating machines, the Proteus from Postojna cave, and the Carniolan Museum Society,' Acta Carsologica, vol. 34, no. 1, pp. 211-220. https://doi.org/10.3986/ac.v34i1.286

Kaiserseder, M. (2013), Die österreichischen Missionsstationen im Sudan zur Mitte des 19. Jahrhunderts-Wegbereiter eines Kolonialismus? Master's thesis defended at the University of Vienna.

Klun, V. F., ed. (1851), Ignaz Knoblecher. Reise auf dem weissen Flusse. Aus den OriginalManiscripen des General-Vicars von Central-Africa, Laibach 1851, Ljubljana: I. Kleinmayer \& F. Bamberg. 
Knoblehar, I. \& Koller, M. (1859a), 'Wasserhöhen des Blues Nils in Jahre 1849,' Jahrbücher der k.k. Centralanstalt für Meteorologie und Erdmagnetismus 1854, Wien, vol. 6, p. 528.

Knoblehar, I. \& Koller, M. (1859b), 'Tagebuch währen einer Reise auf den Weisen Nil non 13. November 1849 bis 16. Jänner 1850,' Jahrbücher der k.k. Centralanstalt für Meteorologie und Erdmagnetismus 1854, Wien, vol. 6, pp. 529-533.

Koller, M. (1850), 'Bericht über die vom Professor Dr. Böhm Abhandlung Beobachtungen von Sonnenflecken und Bestimmung der Rotations-Elemente der Sonne,' Sitzungsberichte der mathematisch-naturwissenschaftlichen Classe der kaiserlichen Akademie der Wissenschaften, vol. 5/7, pp. 150-153.

Koller, M. (1861-1864), Notes on the Lectures of Dr. J. Stefan: (a) 'Theorie der Elasticität fester Körper,' in winter semester 1861/62, followed by acoustic in next summer semester, 36 folios; (b) 'Über die Theorie der Wärme,' lectured during winter semester 1862/63, 35 folios. L. Boltzmann attended those lectures a year and a half later in summer semester 1863/64; (c) 'Über Elektrodynamik und Theorie der Induction,' taught in summer semester 1862/63, 26 folios; (d) 'Über die Theorie des Lichtes,' taught in winter semester 1863/64, 30 folios; (e) 'Über Interferenz, Beugung, Polarisation,' taught in summer semester 1863/64, 10 folios (Manuscript, Directions-Archive of the Sternwarte Kremsmünster).

Kotschy, T. (1865), 'De plantis nilotico-aethiopicis Knoblecherianis,' Sitzungsberichte der mathematisch-naturwissenschaftlichen Klasse der kaiserlichen Akademie der Wissenschaften, vol. 50, pp. 351-365.

Kreil, K. (1857), 'Über zwei Reihen meteorologischer Beobachtungen in den afrikanischen Missions-Stationen Chartum und Gondokoró,' Sitzungsberichte der mathematischnaturwissenschaftichen Klasse der kaiserlichen Akademie der Wissenschaften, vol. 25, pp. 476-488.

Kreil, K. (1858), 'Resultate der fünfmonatlichen Beobachtungen in Chartum und dreimonatlichen Beobachtungen in Ulibary, Denkschriften der Kaiserlichen Akademie der Wissenschaften. Mathematisch-naturwissenschaftliche Klasse, vol. 15/1, pp. 37-68.

Leuckart, F. S. (1840), (Amtlicher) Bericht über die Versammlung Deutscher Naturforscher und Ärzte, in Freiburg in 1838, Freiburg: Emmerling.

Lukas, F. (1859), 'Geographische Skizze zum verschiedenen Tagebuche,' Jahrbücher der k.k. Centralanstalt für Meteorologie und Erdmagnetismus 1854, Wien, vol. 6, pp. 533-536.

Lutstorf, H. T. (1893), Professor Rudolf Wolf und seine Zeit 1816-1893, Band 31, Zürich: Schriftenreihe der ETH-Bibliothek.

Meschutar, A. (1851), 'Ein Aufruf' [A call], in Die Mission von Central-Afrika zur Bekehrung der Neger und der Marien-Verein (The mission of Central Africa to convert the Negroes and the Mary's Association), Wien: k.k. Hof- und Staatsdr.

Reden, F. W. O. L. (1857), 'Ueberblick der bisherigen Thätigkeit (Tätigkeit) und Erfolge österreichischer geistlicher und weltlicher Sendboten in Central-Afrika,' 
Mitteilungen der k.k. Geographischen Gesellschaft, vol. 1, pp. 150-160, 169.

Stefan Archive (1858-1878), AT-OeStA/AVA Unterricht UM Unterrichtsministerium, 1848-1940, AT-OeStA/AVA Unterricht UM (Ministerium für Kultus und Unterricht, OSTA, 1), 4 Phil. Stefan. 1 6215/1858, Stefan, J. (1858-1878): Universitäts Akten, fol. 1-4, Ministerium für Kultus und Unterricht; Personalakts J. Stefan: Four folios of documents on Stefan's career at the University of the Habsburg Ministry of Education and Worship (Kultus und Unterricht), including the documents dated to January 26, 1863, February 9, 1863 (pp. i-iv), September 20, 1866 (pp. 1-12).

Wolf, R. \& Larcher, V. (1993), Rudolf Wolfs Jugendtagebuch 1835-1841 (Rudolf Wolf's juvenile diary, 1835-1841), Band 30, Zürich: Schriftenreihe der ETH-Bibliothek.

Stanislav Južnič was born in San Francisco and obtained US and Slovenian citizenship. He has published about one thousand research works (articles, books) in Chinese and almost all European languages in China, Japan, USA, Australia, Russia, and many European countries. 